\title{
The mitochondrial genomes of two walnut pests, Gastrolina depressa depressa and G. depressa thoracica (Coleoptera: Chrysomelidae), and phylogenetic analyses
}

\author{
Qiqi Wang ${ }^{1,2,3}$, Guanghui Tang ${ }^{\text {Corresp. } 1}$ \\ ${ }^{1}$ Key Laboratory of State Forestry Administration on Management of Western Forest Bio-Disaster, College of Forestry, Northwest A\&F University, Yangling, \\ Shaanxi, China \\ 2 Key Laboratory of Zoological Systematics and Evolution, Institute of Zoology, Chinese Academy of Sciences, Beijing, China \\ 3 University of Chinese Academy of Sciences, Beijing, China \\ Corresponding Author: Guanghui Tang \\ Email address: tanggh@nwsuaf.edu.cn \\ In this study, the mitochondrial genomes (mitogenomes) of two walnut leaf insect pests, \\ Gastrolina depressa depressa and G. depressa thoracica, were sequenced by Sanger \\ sequencing technology. The mitogenome of $G$. depressa thoracica was complete at 16,109 \\ bp in length, while the mitogenome of $G$. depressa depressa $(14,277 \mathrm{bp})$ was partial. The \\ genomic analyses indicated that both mitogenomes have the typical gene content and \\ arrangement. The formerly identified elements, 'TAGTA' between trnSer(UCN) and nad2, \\ and 'ATGATAA' between atp8 and atp6, were more conserved than that between nad $4 L$ \\ and nad4, which was 'ATGTTAA' in Coleoptera excluding Polyphaga. Phylogenetic analyses \\ of the 13 protein-coding genes from 36 coleopteran species well supported a close affinity \\ between the subfamily Chrysomelinae including $G$. depressa thoracica and $G$. depressa \\ depressa and Galerucinae, as well as a sister relationship of ((Eumolpinae + \\ Cryptocephalinae) + Cassidinae) within Chrysomelidae.
}


1 The mitochondrial genomes of two walnut pests, Gastrolina depressa depressa

2 and G. depressa thoracica (Coleoptera: Chrysomelidae), and phylogenetic

3 analyses

4 Qiqi Wang ${ }^{1,2,3}$, Guanghui Tang ${ }^{1, *}$

51 Key Laboratory of State Forestry Administration on Management of Western Forest Bio-Disaster,

6 College of Forestry, Northwest A\&F University, Yangling, 712100, China

2 Key Laboratory of Zoological Systematics and Evolution, Institute of Zoology, Chinese Academy of Sciences, Beijing, 100101, China

3 University of Chinese Academy of Sciences, Beijing, 100049, China

*Correspondence: tanggh@nwafu.edu.cn

In this study, the mitochondrial genomes (mitogenomes) of two walnut leaf insect pests, Gastrolina depressa depressa and $G$. depressa thoracica, were sequenced by Sanger sequencing technology. The mitogenome of $G$.

bp) was partial. The genomic analyses indicated that both mitogenomes have the typical gene content and arrangement. The formerly identified elements, 'TAGTA' between $\operatorname{trn} \operatorname{Ser}(U C N)$ and $n a d 2$, and 'ATGATAA' between atp 8 and atp6, were more conserved than that between nad4L and nad4, which was 'ATGTTAA' in

21 + Cassidinae) within Chrysomelidae. 


\section{Introduction}

Both Gastrolina depressa thoracica and G. depressa depressa belong to Chrysomelinae (Coleoptera: Chrysomeloidea) and are the major insect pests of walnut in China. The larvae and adults feed on walnut leaves, and seriously influence walnut growth and yield. Compared with other species of Chrysomelinae in the boundary between Palaearctic and oriental regions, they have a typical flat back. Furthermore, G. depressa thoracica has a black prothorax, while G. depressa depressa has a yellow prothorax (Chen, 1974). Ge et al. (2003) comprehensively compared the morphological differences and the distributions of G. depressa thoracica and $G$. depressa depressa. Overall, in China G. depressa depressa are widely distributed in most areas south of the Yellow River, while G. depressa thoracica live in north of the Yangtze River. They both have filamentous antennae, and similar structure of the hind wing, claw and upper lip, but there are large differences in the structure of lower lip (cilia: long and dense in G. depressa thoracica, short and sparse in G. depressa depressa) and lower jaw (between the anterior chin and lower lip: triangle in G. depressa thoracica, circular soliton in G. depressa depressa). However, there is no information about their mitochondrial genomes (mitogenomes) or any other molecular data to support their classification.

Mitogenomes have been widely used as molecular markers for phylogenetics and phylogeographics because of maternal inheritance, conserved gene order and orientation, low recombination rate and high mutation rate (Avise, 1989; Crozier \& Crozier, 1993; Jin et al., 2004). In general, the mitogenomes range from 14 to $36 \mathrm{~kb}$ in length, encoding 13 protein-coding genes (PCGs), 22 transfer RNA genes (tRNAs), 2 ribosomal RNA genes (rRNAs) and a large non-coding region (control region or A+T-rich region) (Wolstenholme, 1992; Boore et al., 1998). Recent advances in sequencing technology have enriched insect genome and mitogenome datasets and accelerated insect molecular studies. Insect genome and mitogenome data are now widely used in species identification, population genetics and molecular evolution (Ma et al., 2012; Timmermans et al., 2014).

Coleoptera has as many as 380,000 described species and an estimated total number of about three million members. Cucujiformia is one of the most highly diversified infraorders of Polyphaga (Crowson, 1960; ØDegaard, 2000; Foottit \& Adler, 2009) and includes six superfamilies, among which the superfamilies Curculionoidea and Chrysomeloidea are the major plant-feeding beetles (Grimaldi \& Engel, 2005). Several studies have reported the phylogenetic relationships within Chrysomeloidea by using morphological data (Farrell \& Sequeira, 2004; Gómez-Zurita et al., 2007), 18S rRNA (Hunt et al., 2007), 28S rDNA (Marvaldi et al., 2009), and partial mitochondrial genes (Bocak et al., 2014; Li et al., 2016).

In this study, we sequenced the mitochondrial genomes of G. depressa thoracica and G. depressa depressa and clarified their mitogenome differences. The nucleotide and amino acid sequences of the 13 PCGs of two walnut pest insects were then aligned with data of 34 other coleopteran species for the phylogenetic analyses.

\section{Materials and Methods}

\section{Sample collection}

Adults of $G$. depressa thoracica and $G$. depressa depressa were originally collected from the experimental 
station of Northwest A\&F University, Shanyang County, Shaanxi Province, China $\left(109^{\circ} 88^{\prime} \mathrm{E}, 33^{\circ} 53^{\prime} \mathrm{N}\right)$, and identified according to key morphological characteristics. All samples were stored in $100 \%$ ethanol at $-20^{\circ} \mathrm{C}$.

\section{DNA extraction and PCR amplification}

Total genomic DNA was extracted from an individual insect using a standard phenol-chloroform extraction (Tamura \& Aotsuka, 1988). The specific primers of each mitochondrial gene (Table 1) were designed from the conserved regions after multiple alignments of coleopteran insect mitochondrial sequences. PCR was performed with a 3-step program: an initial denaturation at $94{ }^{\circ} \mathrm{C}$ for $2 \mathrm{~min}$; followed by 35 cycles at $94{ }^{\circ} \mathrm{C}$ for $30 \mathrm{~s}$, annealing temperature (Table 1) for $30 \mathrm{~s}, 72{ }^{\circ} \mathrm{C}$ for $1 \mathrm{~min}$; and a final extension at $72{ }^{\circ} \mathrm{C}$ for $10 \mathrm{~min}$. PCR products (1.1-4.1 Kb in length) were analyzed by $1 \%$ agarose gel electrophoresis, and sequenced.

\section{Genome assembly and annotation}

All sequences were blasted in NCBI (https://www.ncbi.nlm.nih.gov/) and assembled using the program SeqMan in DNAStar package v7.1 (DNAStar Inc., Madison, WI, USA). The 13 PCGs were identified using ORF Finder (available on NCBI) and the rRNAs were determined by comparison with other coleopteran mitogenomes. The tRNAs and their cloverleaf secondary structures were predicted using tRNAscan-SE Search Online Server (Lowe \& Eddy, 1997), while undefined tRNAs were further compared with tRNAs of other species, including Atrijuglans hetaohei (Wang et al., 2016), Dastarcus helophoroides (Zhang et al., 2015) and Anopheles minimus (Hua et al., 2016). The secondary structure of all tRNAs were drawn using RNAviz v2.0 (De Rijk et al., 2003). The composition of nucleotide sequences was described by skewness according to the following formulas (Perna $\&$ Kocher, 1995): AT-skew $=(\mathrm{A}-\mathrm{T}) /(\mathrm{A}+\mathrm{T})$ and $\mathrm{GC}$-skew $=(\mathrm{G}-\mathrm{C}) /(\mathrm{G}+\mathrm{C})$. The $\mathrm{A}+\mathrm{T}$ content and relative synonymous codon usage (RSCU) were calculated using MEGA v5.1 (Tamura et al., 2011).

\section{Phylogenetic analysis}

The newly sequenced mitogenomes of $G$. depressa thoracica and G. depressa depressa were aligned with 32 mitochondrial genomes of Chrysomeloidea available in GenBank, with Tetraphalerus bruchi (Coleoptera: Archostemata: Ommatidae) and Abax parallelepipedus (Coleoptera: Adephaga: Carabidae) as outgroups (Table S1). The nucleotide and amino acid sequences of 13 PCGs from all 36 species were aligned separately using ClustalW implemented in MEGA v5.1 (Tamura et al., 2011). Gblocks v0.91b (Talavera \& Castresana, 2007) was used to refine the final alignments and identify the conserved sequences (or conserved motifs). After Gblocks analysis, the final matrix consisted of 7289 nucleotides and 2340 amino acids. The best-fit models $(\mathrm{TVM}+\mathrm{I}+\mathrm{G}$ for the nucleotide dataset and MtREV $+\mathrm{I}+\mathrm{G}+\mathrm{F}$ for amino acid dataset) were selected using MrModeltest v2.3 (Nylander, 2004) and ProtTest v2.4 (Abascal et al., 2005) with specific parameters (Table S2).

Phylogenetic trees of PCGs were constructed using maximum likelihood (ML) and Bayesian inference (BI); these two methods (ML and BI) have different algorithms in phylogenetic analyses. In ML analyses, phylogenetic trees of nucleotide and amino acid sequences were constructed by PhyML v3.0 (Guindon et al., 2010) based on the best-fit model (as above) with 1000 replicates. For BI analysis, MrBayes v3.2.6 (Huelsenbeck 
106

107

108

109

110

111

112

113

114

115

116

117

118

119

120

121

122

123

124

125

126

127

128

129

130

131

132

133

134

135

136

137

138

139

140

\& Ronquist, 2001) was used to compute the probability distribution and get a sharper and stronger prediction; four simultaneous Markov chains ran for 10 million generations and sampled every 1000 generations after discarding the first $25 \%$ "burn-in" trees. Node support was assessed by the value of Bayesian posterior probabilities (BPP). The consensus trees were viewed and edited by Figtree v1.4.3 (Rambaut, 2009).

\section{Results and Discussion}

\section{Gene content and nucleotide composition}

The mitogenomes of $G$. depressa thoracica and $G$. depressa depressa were sequenced. The complete $G$. depressa thoracica mitogenome had 16, 109 bp, including 13 PCGs, 2 rRNAs and 22 tRNAs, and an A+T-rich region (Fig 1, Table 2). In the mitogenome of G. depressa thoracica, there were four intergenic spacers (a total length of $23 \mathrm{bp}$ ), ranging from $1 \mathrm{bp}$ to $17 \mathrm{bp}$, and the longest intergenic spacer was located between $\operatorname{trnSer}(A G N)$ and nad1. Furthermore, 15 pairs of genes overlapped each other, with a length ranging from 1 to $17 \mathrm{bp}$.

The sequenced mitogenome of $G$. depressa depressa was partial and 14, $277 \mathrm{bp}$ long, including 13 PCGs, 21 tRNAs, $r r n L$ and partial $r r n S$ (550 nucleotides from the 3'-end) (Fig 1, Table 2). The A+T-rich region, trnI and partial $r r n S$ (predicted to be about 200 nucleotides from the 5'-end) were failed to be sequenced although we have tried several pairs of species-specific primers. There were 3 intergenic spacers ( $23 \mathrm{bp}$ ), ranging from $1 \mathrm{bp}$ to $17 \mathrm{bp}$, and the longest intergenic spacer was detected between $\operatorname{trn} \operatorname{Ser}(A G N)$ and nad1. Seventeen pairs of genes overlapped each other, with a length ranging from 1 to $20 \mathrm{bp}$.

Two 7-bp long overlaps (ATGATAA) were detected in both G. depressa depressa and G. depressa thoracica, which were also found in many other Polyphaga insects (Fig 2). The overlaps were located between atp8 and atp6 on the H-strand and between nad $4 L$ and nad4 on the L-strand, respectively. The overlapped sequences were thought to be translated as a bicstron (Stewart \& Beckenbach, 2005). Another 5 bp long motif sequence (TAGTA) was detected between $\operatorname{trnSer}(U C N)$ and nadl in mitogenomes of $G$. depressa depressa and $G$. depressa thoracica, which was also present in other coleopterans (Fig 3). This consensus sequence has been proposed as the possible binding site of mtTERM because it is located at the end of the H-strand coding region in the circular mitogenome (Taanman, 1999). The sequenced motifs between atp 8 and atp6, and between $\operatorname{trnSer}(U C N)$ and $n a d l$ were relatively conserved in four suborders (41 Polyphaga, 24 Adephaga, 2 Archostemata and 2 Myxophaga) after mitogenomic comparisons. However, the motif 'ATGATAA' between nad4 and nad4L was only found in the mitogenomes of Polyphaga insects, while 'ATGTTAA' was identified in insect mitogenomes from the other three suborders, Adephaga, Archostemata and Myxophaga (Fig S1).

\section{Protein-coding genes}

In the mitogenomes of G. depressa thoracica and G. depressa depressa, a total of 3731 and 3678 amino acids were encoded by $11,182 \mathrm{bp}$ and 11,026 bp nucleotides, respectively. All genes had the same orientations and organization. The 13 PCGs ranged from $156 \mathrm{bp}$ (atp8) to $1722 \mathrm{bp}$ (nad5) for G. depressa thoracica and from $156 \mathrm{bp}$ (atp8) to $1728 \mathrm{bp}$ (nad5) for G. depressa depressa (Table 2). Except for nad1 which used TTG as a start codon, all other PCGs had the typical ATN as the start codon. For example, nad2, coxl, cox2 and nad5 have 
141 'ATT' as start codon, while the start codon 'ATA' was used for nad3 and nad6, 'ATG' for atp6, cox3, nad4, $142 n a d 4 L$ and $c o b$, and 'ATC' for atp 8 in $G$. depressa thoracica mitogenome. In G. depressa depressa mitogenome, 143 start codon 'ATT' was used in six genes (nad2, cox1, cox2, atp8, nad5 and nad6), 'ATG' for atp6, cox3, nad4, $144 n a d 4 L$ and $c o b$, and 'ATC' for nad3. The stop codons for the two mitogenomes were TAA, TAG and incomplete 145 termination codons, like TA or T (Table 3). The incomplete stop codons could be completed as TAA through post-transcriptional polyadenylation (Ojala et al., 1981; Boore, 2004).

147 The A+T content, AT-skew and GC-skew of G. depressa thoracica, G. depressa depressa and three other 148 Chrysomelidae were calculated, respectively. All PCGs have a high A+T percentage (70\%) (Table 3). This 149 indicated that PCGs have the high background mutational pressure toward AT nucleotides at the third codon 150 position (Kim et al., 2014).

151 The relative synonymous codon usage (RSCU) showed that the most frequently used amino acids in these two 152 mitogenomes were Leu, Ile, Phe and Met. TTA for Leu, ATT for Ile, TTT for Phe and ATA for Met were the most popular codons in $G$. depressa thoracica and G. depressa depressa mitogenomes (Fig 4, Fig 5). The sum of the most popular amino acids, like Leu, Ile, Phe and Met, varied from 38\% (Agasicles hygrophila) to 42.23\% (G. depressa depressa). All PCGs are rich with A or T nucleotides, which was also found in other coleopteran insects (Kim et al., 2009; Du et al., 2016).

The codon families in PCGs were encoded by H and L strands (Fig 6), respectively. The amino acid abundance of PCGs on H and L strands have different skewness, which led to an amino acid usage unbalance in PCGs. PCGs on the H-strand were more TA-skewed than CG-skewed, whereas the PCGs on the L-strand had a higher frequency of T and G, in which the first and second codons were skewed toward A nucleotide (Pons et al., 2010). Similarly, the third codon was also A/T biased (Fig 6). Overall, this nucleotide preference lead to 13 PCGs having a higher percentage of Leu and a lower percentage of Cys. However, nad genes on the L-strand (nad1, nad5, nad4 and nad4L) encode more Cys $(\geqslant 2)$ than any other genes on the H-strand (only 1-2) (Table S3). Four-fold degenerate codon usage was obviously A/T biased in the third position, and two-fold degenerate codon usage showed a similarly biased pattern, with A/T favored over G/C in the third position (Fig 6). Both patterns were in agreement with the AT-biased content exhibited by PCGs. The most obvious bias of amino acid usage was due to structural/functional requirements of PCGs, which is well represented by the distribution of the Cys codon family. For example, mitochondrial nad genes have the highest Cys content, which are essential structures and help to form intra- and inter-chain disulfide (Mishmar et al., 2006).

\section{Transfer RNA genes}

Twenty-two tRNAs were found in G. depressa thoracica and ranged from 62 bp to 71 bp in length with 14 tRNAs on the H-strand and 8 on the L-strand. Except for $\operatorname{trnSer}(A G N)$, all tRNAs were folded into the typical

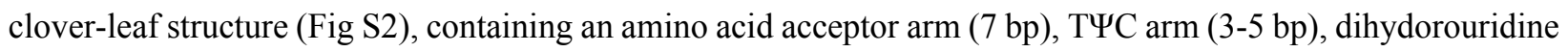
(DHU) arm (3-4 bp), anticodon arm (3-5 bp) and a variable extra arm. In the mitogenome of G. depressa depressa, 21 tRNAs were identified (Fig S2) and the length of these genes were between 62 bp to 70 bp, in 
which 13 and 8 tRNAs were encoded by the H-strand and L-strand, respectively. Twenty tRNAs had the typical

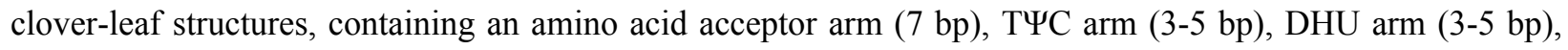
anticodon arm (3-5 bp) and a variable extra arm. However, $\operatorname{trnSer}(A G N)$ did not have the DHU arm, and formed a simple-loop structure, which is a common phenomenon in many insect mitogenomes (Wolstenholme, 1992).

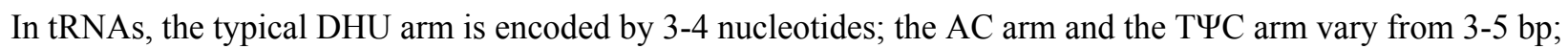
and the variable loops range from 4-6 bp. In general, the size of the variable loop and the D-loop affects the length of the tRNA (Navajas et al., 2002). In the comparison of both mitochondrial genomes (Fig S2), the major base pairs, A-T and G-C in stem regions are Watson-Crick pairs, while G-U wobble and mismatched pairs can also be observed. A total of 18 and $12 \mathrm{G}-\mathrm{U}$ wobbles were observed in the mitogenomes of G. depressa thoracica and $G$. depressa depressa, with 10, 4, 3, 1 and 3, 4, 4, 1 base pairs in AA stem, D stem, AC stem and T stem of the tRNAs, respectively. In these wobbles, three were in the D stems of trnGln, trnPro and trnHis, and one was in the AA stem of trnCys. Except for trnIle, three [one AG in trnTrp, and two UU in trnLeu(UUR) and trnLeu(CUN)] and two [one AG in trnTrp and one UU in trnLeu(UUR)] mismatched base pairs were found in the tRNAs of $G$. depressa thoracica and $G$. depressa depressa mitogenomes, respectively. Among the six mismatched base pairs, four were located in the amino acid acceptor arms, and one UU pair was located in the anticodon arm of trnLeu(CUN). These mismatches, which are apparently deleterious, can be repaired and corrected by a putative RNA editing process (Masta \& Boore, 2004). From protozoa to plants and metazoan animals, tRNA editing events have been observed in a variety of mitochondrial tRNAs (Laforest et al., 1997; Alfonzo et al., 1999; Leigh \& Lang, 2004; Grewe et al., 2009; Knoop, 2011).

The percentage of identical nucleotides (\%INUC) for both insects was calculated (Table S4). TrnD, $\operatorname{trn} N$, $\operatorname{trnR}$, $\operatorname{trn} E, \operatorname{trn} W, \operatorname{trn} S(U C N)$ and $\operatorname{trn} P$ showed a higher \%INUC ( $>90 \%)$ in both insects, and the first six were located on the $\mathrm{H}$ strand (Table 2). Only $\operatorname{trnF}$ and $\operatorname{trnL}(C U N)$ on the L-strand had a lower \%INUC $(<80 \%)$, indicating the level of conservation was positively $\mathrm{H}$ strand-biased.

\section{Phylogenetic analyses}

Phylogenetic trees were constructed based on 13 PCGs nucleotide sequences from 36 species (Fig 7A) and their corresponding amino acid sequences (Fig 7B) by maximum likelihood (ML) and Bayesian Inference (BI) analyses. Overall, BI analyses provided more resolution with strong supports. G. depressa thoracica and $G$. depressa depressa formed one clade (BPP/BS=1/100), and had a closer relationship with species from Galerucinae than G. intermedia from Chrysomelinae.

The family Chrysomelidae was divided into three major clades in both nucleotide and amino acid sequence trees using ML and BI analyses (Fig 7). Chrysomelinae and Galerucinae consistently formed a clade, and the other four subfamilies, Bruchinae, Criocerinae, Donaciinae, and Spilopyrinae, were clustered in a clade. The phylogenetic analyses in this study were also well supported by previous analyses (Farrell, 1998; Reid, 2000; Farrell \& Sequeira, 2004; Gómez-Zurita et al., 2007; Bocak et al., 2014; Song et al., 2017), in which the clade of Eumolpinae + Cryptocephalinae + Cassidinae were close to Galerucinae and Chrysomelinae, with the latter 
211 observed in all the phylogenetic trees.

212 In the phylogenetic analyses of amino acid sequences, Orsodacninae had a closer relationship with the clade of 213 Lepturinae + Necydalinae in the superfamily Cerambycidae. This implied that Orsodacninae might be evaluated 214 outside Chrysomelidae (Haddad \& Mckenna, 2016). Reid (1995) was also against placing Orsodacninae within 215 the Cerambycidae based on mitochondrial nucleotide sequences analyses. The representative species from 216 Lamiinae formed a clade in the four phylogenetic trees, while the interrelationships within Cerambycinae 217 remained unclarified due to insufficient mitogenome and genome data from these insects. Certainly, as more 218 mitogenomes and genomes of insect species are available in databases, phylogenetic analyses will be more 219 reliable and convincing.

\section{Conclusions}

221 In this study, the complete mitogenome of $G$. depressa thoracica $(16,109 \mathrm{bp})$ and the partial mitogenome of $G$. 222 depressa depressa (14,277 bp) were sequenced and analyzed. In the mitogenomes of G. depressa thoracica and 223 G. depressa depressa, the overall mitochondrial gene order and orientation were identical with some exceptions. 224 The motifs, 'TAGTA' between $\operatorname{trnSer}(U C N)$ and nad2, and 'ATGATAA' between atp 8 and atp6, were found 225 to be more conserved than 'ATGATAA' between nad4 and nad $4 L$ in the mitogenomes of Polyphaga, which was 226 'ATGTTAA' in the Adephaga, Myxophaga and Archostemata. Phylogenetic analyses showed that G. depressa thoracica and G. depressa depressa consistently formed a clade. Within Chrysomeloidea, the sister relationships of ((Eumolpinae + Cryptocephalinae $)+$ Cassidinae $)$, and the close affinity of Galerucinae + Chrysomelinae were confirmed with high nodal supports. We believe that the mitogenomes of $G$. depressa thoracica and $G$. depressa depressa will be useful for further studies of molecular classification, and coleopteran mitogenome architecture and phylogenetics. 


\section{References}

Abascal F, Zardoya R, Plsada D. 2005. ProtTest: selection of best-fit models of protein evolution. Bioinformatics 21:2104-2105

Alfonzo J, Blan V, Estévez AM, Rubio MA, Simpson L. 1999. C to U editing of the anticodon of imported mitochondrial tRNA(Trp) allows decoding of the UGA stop codon in Leishmania tarentolae. The Embo Journal 18(24): 7056-7062

An YL, Huang XM, Yang XJ, Lin XJ, Ji BZ, Wang DB, Victor CM. 2004. A study on mtDNA sequence and its genetic characteristics of Anoplophora glabripennis and its sibling species. Journal of Nanjing Forestry University 28(4):6-12

Avise JC. 1989. A role for molecular genetics in the recognition and conservation of endangered species. Trends in Ecology \& Evolution 4:279-281

Bocak L, Barton C, Crampton-Platt A, Chesters D, Ahrens D, Vogler AP. 2014. Building the coleoptera tree-of-life for $>8000$ species: composition of public dna data and fit with linnaean classification. Systematic Entomology 39(1):97-110

Boore JL. 2004. Complete mitochondrial genome sequence of the polychaete annelid Platynereis dumerilii. BMC Genomics 18:1413-1416

Boore JL, Lavrov DV, Brown WM. 1998. Gene translocation links insects and crustaceans. Nature 392:667668

Chen SH. 1974. Key to the species and subspecies of the chrysomelid genus Gastrolina. Acta Entomologica Sinica 17:195-197

Coates BS. 2014. Assembly and annotation of full mitochondrial genomes for the corn rootworm species, Diabrotica virgifera virgifera and Diabrotica barberi (Insecta: Coleoptera: Chrysomelidae), using Next Generation Sequence data. Gene 542(2):190-197

Crowson RA. 1960. The phylogeny of coleopteran. Annual Review of Entomology 5:111-134

Crozier RH, Crozier YC. 1993. The mitochondrial genome of the honeybee Apis mellifera: complete sequence and genome organization. Genetics 133:97-177

De Rijk P, Wuyts J, De Wachter R. 2003. RnaViz 2: an improved representation of RNA secondary structure. Bioinformatics 19:99-300

Dierckxsens N, Mardulyn P, Smits G. 2017. NOVOPlasty: de novo assembly of organelle genomes from whole genome data. Nucleic Acids Research 45(4):e18

Du C, He SL, Song XH, Liao Q, Zhang XY, Yue BS. 2016. The complete mitochondrial genome of Epicauta chinensis (Coleoptera: Meloidae) and phylogenetic analysis among coleopteran insects. Gene 578:274

Farrell BD, Sequeira AS. 2004. Evolutionary rates in the adaptive radiation of beetles on plants. Evolution 58:1984-2001

Farrell BD. 1998. "Inordinate Fondness" explained: why are there so many beetles? Science 281:555-559.

Foottit RG, Adler PH. 2009. Chapter 11. Biodiversity of Coleoptera. Insect Biodiversity: Science and Society 
265-301

Ge SQ, Yang XK, Wang SY, Cui JZ, Li WZ. 2003. A revision of the taxonomic status of three subspecies of Gastrolina depressa Baly (Coleoptera: Chrysomelidae, Chrysomelinae). Acta Entomologica Sinica 46:512-518

Gómez-Rodríguez C, Crampton-Platt A, Timmermans MJTN, Baselga A, Vogler AP. 2015. Validating the power of mitochondrial metagenomics for community ecology and phylogenetics of complex assemblages. Methods in Ecology and Evolution 6(8):883-894

Gómez-Zurita J, Hunt T, Kopliku F, Vogler AP. 2007. Recalibrated tree of leaf beetles (Chrysomelidae) indicates independent diversification of angiosperms and their insect herbivores. PLOS ONE 2:e360

Grewe F, Viehoever P, Weisshaar B, Knoop V. 2009. A trans-splicing group I intron and tRNA-hyperediting in the mitochondrial genome of the lycophyte Isoetes engelmannii. Nucleic Acids Research 37(15):50935104

Grimaldi D, Engel MS. 2005. Evolution of the Insects. Cambridge: Cambridge University Press

Guindon S, Dufayard JF, Lefort V, Anisimova M, Hordijk W, Gascuel O. 2010. New algorithms and methods to estimate maximum-likelihood phylogenies: assessing the performance of PhyML 3.0. Systematic Biology 59(3):307-321

Haddad S, Mckenna DD. 2016. Phylogeny and evolution of the superfamily Chrysomeloidea (Coleoptera: Cucujiformia). Systematic Entomology 41(4):697-716

Hua YQ, Ding YR,Yan ZT, Si FL, Luo QC, Chen B. 2016. The complete mitochondrial genome of Anopheles minimus (Diptera: Culicidae) and the phylogenetics of known Anopheles mitogenomes. Insect Science 23:353-365

Huelsenbeck JP, Ronquist F. 2001. Mrbayes: bayesian inference of phylogenetic trees. Bioinformatics 17:754755

Hunt, T, Bergsten J, Levkanicova Z, Papadopoulou A, St. John O, Wild R, Hammond PM, Ahrens D, Balke M, Caterino MS, Gómez-Zurita J, Ribera I, Barraclough TG, Bocakova M, Bocak L, Vogler AP. 2007. A comprehensive phylogeny of beetles reveals the evolutionary origins of a superradiation. Science 318: 1913-1916

Jie Y, Hong Y, Dai RH. 2017. Characterization of the complete mitochondrial genome of Acanthoscelides Obtectus (Coleoptera: Chrysomelidae: Bruchinae) with phylogenetic analysis. Genetica 145(4-5):397-408

Jin SB, Kim I, Sohn HD, Jin BR. 2004. The mitochondrial genome of the firefly, Pyrocoelia rufa: complete DNA sequence, genome organization and phylogenetic analysis with other insects. Molecular Biology and Evolution 32:978-985

Kim KG, Hong MY, Kim MJ, Im HH, Kim M II, Bae CH, Seo SJ, Lee SH, Kim I. 2009. Complete mitochondrial genome sequence of the yellow-spotted long-horned beetle Psacothea hilaris (Coleoptera: Cerambycidae) and phylogenetic analysis among coleopteran insects. Molecules and Cells 27:429-441

Kim MJ, Wang AR, Park JS, Kim I. 2014. Complete mitochondrial genomes of five skippers (Lepidoptera: 
Hesperiidae) and phylogenetic reconstruction of Lepidoptera. Gene 549:97-112

Knoop V. 2011. When you can't trust the DNA: RNA editing changes transcript sequences. Cellular and Molecular Life Science 68(4):567-586

Laforest MJ, Roewer I, Lang BF. 1997. Mitochondrial trnas in the lower fungus Spizellomyces punctatus: tRNA editing and UAG 'stop' codons recognized as leucine. Nucleic Acids Research 25(3):626-632

Leigh J, Lang BF. 2004. Mitochondrial 3' tRNA editing in the jakobid Seculamonas ecuadoriensis: a novel mechanism and implications for tRNA processing. RNA 10(4): 615-621

Li WB, Yang XJ, Qian L, An YL, Fang J. 2015. The complete mitochondrial genome of the citrus long-horned beetle, Anoplophora chinensis (Coleoptera: Cerambycidae). Mitochondrial Dna A Dna Mapp Seq 27(6):4665-4667

Li XJ, Ou J, Wei ZM, Li YX, Tian YF. 2016. The mitogenomes of three beetles (Coleoptera: Polyphaga: Cucujiformia): new gene rearrangement and phylogeny. Biochemical Systematics and Ecology 69:101107

Linard B, Arribas P, Andújar C, Crampton-Platt A, Vogler AP. 2016. Lessons from genome skimming of arthropod-preserving ethanol. Molecular Ecology Resources 16(6):1365-1377

Lowe TM, Eddy SR. 1997. tRNAscan-SE: a program for improved detection of transfer RNA genes in genomic sequence. Nucleic Acids Research 25:955-964

Ma C, Yang PC, Jiang F, Chapuis MP, Shali Y, Sword GA, Kang L. 2012. Mitochondrial genomes reveal the global phylogeography and dispersal routes of the migratory locust. Molecular Ecology 21:4344-4358

Marvaldi AE, Duckett CN, Kjer KM, Gillespie JJ. 2009. Structural alignment of 18s and 28s rdna sequences provides insights into phylogeny of Phytophaga (Coleoptera: Curculionoidea and Chrysomeloidea). Zoologica Scripta 38(1):63-77.

Masta SE, Boore JL. 2004. The complete mitochondrial genome sequence of the spider Habronattus oregonensis reveals rearranged and extremely truncated tRNAs. Molecular Biology and Evolution 21(5):893-902

Mishmar D, Ruiz-Pesini E, Mondragon-Palomino M, Procaccio V, Gaut B, Wallace DC. 2006. Adaptive selection of mitochondrial complex I subunits during primate radiation. Gene 378(3): 11-18

Navajas M, Le Conte Y, Solignac M, Cros-Arteil S, Cornuet JM. 2002. The complete sequence of the mitochondrial genome of the honeybee ectoparasite mite Varroa destructor (Acari: Mesostigmata). Molecular Biology and Evolution 19(12):2313-2317

Nie RE, Lin MY, Xue HJ, Bai M, Yang XK. 2015. Complete mitochondrial genome of Spiniphilus spinicornis (Coleoptera: Vesperidae: Philinae) and phylogenetic analysis among Cerambycoidea. Mitochondrial Dna A Dna Mapp Seq 28(1):145-146

Nylander JAA. 2004. MrModeltest Version 2. Evolutionary Biology Centre. Uppsala: Uppsala University

ØDegaard F. 2000. How many species of arthropods? Erwin's estimate revised. Biological Journal of the Linnean Society 71:583-597

Ojala D, Montoya J, Attardi G. 1981. tRNA punctuation model of RNA processing in human mitochondria. 
Nature 290:470-474

Perna NT, Kocher TD. 1995. Patterns of nucleotide composition at fourfold degenerate sites of animal mitochondrial genomes. Journal of Molecular Evolution 41:353-358

Pons J, Ribera I, Bertranpetit J, Balke M. 2010. Nucleotide substitution rates for the full set of mitochondrial protein-coding genes in Coleoptera. Molecular Biology and Evolution 56:796-807

Rambaut A. 2009. FigTree v1.3.1. Available at http://tree.bio.ed.ac.uk/software/ (accessed on 31 September 2017)

Reid CAM. 1995. A cladistic analysis of subfamilial relationships in the Chrysomelidae sensu lato (Chrysomeloidea). In: Pakaluk J, Slipinski SA, Muzeum I, eds. Biology, Phylogeny and classification of Coleoptera: papers celebrating the 80th birthday of Roy A. Crowson. Instytut Zoologii PAN: Warszaw, Poland

Reid CAM. 2000. Spilopyrinae Chapuis: a new subfamily in the Chrysomelidae and its systematic placement (Coleoptera). Invertebrate Taxonomy 14:837-862

Sheffield NC, Song H, Cameron SL, Whiting MF. 2008. A comparative analysis of mitochondrial genomes in Coleoptera (Arthropoda: Insecta) and genome descriptions of six new beetles. Molecular Biology and Evolution 25(11):2499-2509

Song N, Yin XM, Zhao XC, Chen JH, Yin J. 2017. Reconstruction of mitogenomes by NGS and phylogenetic implications for leaf beetles. Mitochondrial Dna A Dna Mapp Seq Anal 1-10

Song N, Zhang H, Yin XM, Lin AL, Zhai Q. 2015. The complete mitochondrial genome sequence from the longicorn beetle Obrium sp. (Coleoptera: Cerambycidae). Mitochondrial Dna A Dna Mapp Seq Anal 28(3):326-327

Stewart JB, Beckenbach AT. 2003. Phylogenetic and genomic analysis of the complete mitochondrial DNA sequence of the spotted asparagus beetle Crioceris duodecimpunctata. Molecular Phylogenetics and Evolution 26(3):513-526

Stewart JB, Beckenbach AT. 2005. Insect mitochondrial genomics: the complete mitochondrial genome sequence of the meadow spittlebug Philaenus spumarius (Hemiptera: Auchenorrhyncha: Cercopoidae). Genome 48:46-54

Taanman JW. 1999. The human mitochondrial genome: structure, transcription, translation and replication. Biochimica Biophysica Acta 1410:103-123

Talavera G, Castresana J. 2007. Improvement of phylogenies after removing divergent and ambiguously aligned blocks from protein sequence alignments. Systematic Biology 56:564-577

Tamura K, Aotsuka T. 1988. Rapid isolation method of animal mitochondrial DNA by the alkaline lysis procedure. Biochemical Genetics 26:815-819

Tamura K, Peterson D, Peterson N, Stecher G, Nei M, Kumar S. 2011. MEGA5: molecular evolutionary genetics analysis using maximum likelihood, evolutionary distance, and maximum parsimony methods. Molecular Biology and Evolution 28:2731-2739 
Timmermans MJ, Barton C, Haran J, Ahrens D, Culverwell CL, Ollikainen A, Dodsworth S, Foster PG, Bocak L, Vogler AP. 2015. Family-level sampling of mitochondrial genomes in Coleoptera: compositional heterogeneity and phylogenetics. Genome Biology and Evolution 8(1):161-175

Timmermans MJ, Lees DC, Simonsen TJ. 2014. Towards a mitogenomic phylogeny of Lepidoptera. Molecular Biology and Evolution 7:169-178

Wang QQ, Zhang ZQ, Tang GH. 2016. The mitochondrial genome of Atrijuglans hetaohei Yang (Lepidoptera: Gelechioidea) and related phylogenetic analyses. Gene 581:66-74

Wang QQ, Tang GH. 2017. Genomic and phylogenetic analysis of the complete mitochondrial DNA sequence of walnut leaf pest Paleosepharia posticata (Coleoptera: Chrysomeloidea). Journal of Asia-Pacific Entomology 20(3):840-853

Wang YT, Liu YX, Tong XL, Ren QP, Jiang GF. 2014. The complete mitochondrial genome of the longhorn beetle, Massicus raddei. Mitochondrial Dna A Dna Mapp Seq Anal 27(1):209-211

Wolstenholme DR. 1992. Animal mitochondrial DNA: structure and evolution. International Review of Cytology 141:173-216

Zhang ZQ, Wang XJ, Li RZ, Guo RJ, Zhang W, Song W, Hao CF, Wang HP, Li ML. 2015. The mitochondrial genome of Dastarcus helophoroides (Coleoptera: Bothrideridae) and related phylogenetic analyses. Gene 560: 15-24

Zhou XR, Han HB, Pang BP, Zhang PF. 2016. The complete mitochondrial genome of Galeruca daurica (Joannis) (Coleoptera: Chrysomelidae). Mitochondrial Dna A Dna Mapp Seq Anal 27(4):2891-2892 
Figure 1

Gene maps of the complete mitochondrial genome for $(A) G$. depressa thoracica and the incomplete mitochondrial genome for (B) G. depressa depressa.

The PCGs and rRNAs are the standard abbreviations. Each tRNA is denoted as a one-letter symbol according to the IUPAC-IUB single-letter amino acid codes. Arrows indicate coding direction. The unmarked region, whole A+T-rich region, trnl and partial $r r n S$, are failed to be sequenced. Photos of the two insects were taken by Guanghui Tang.
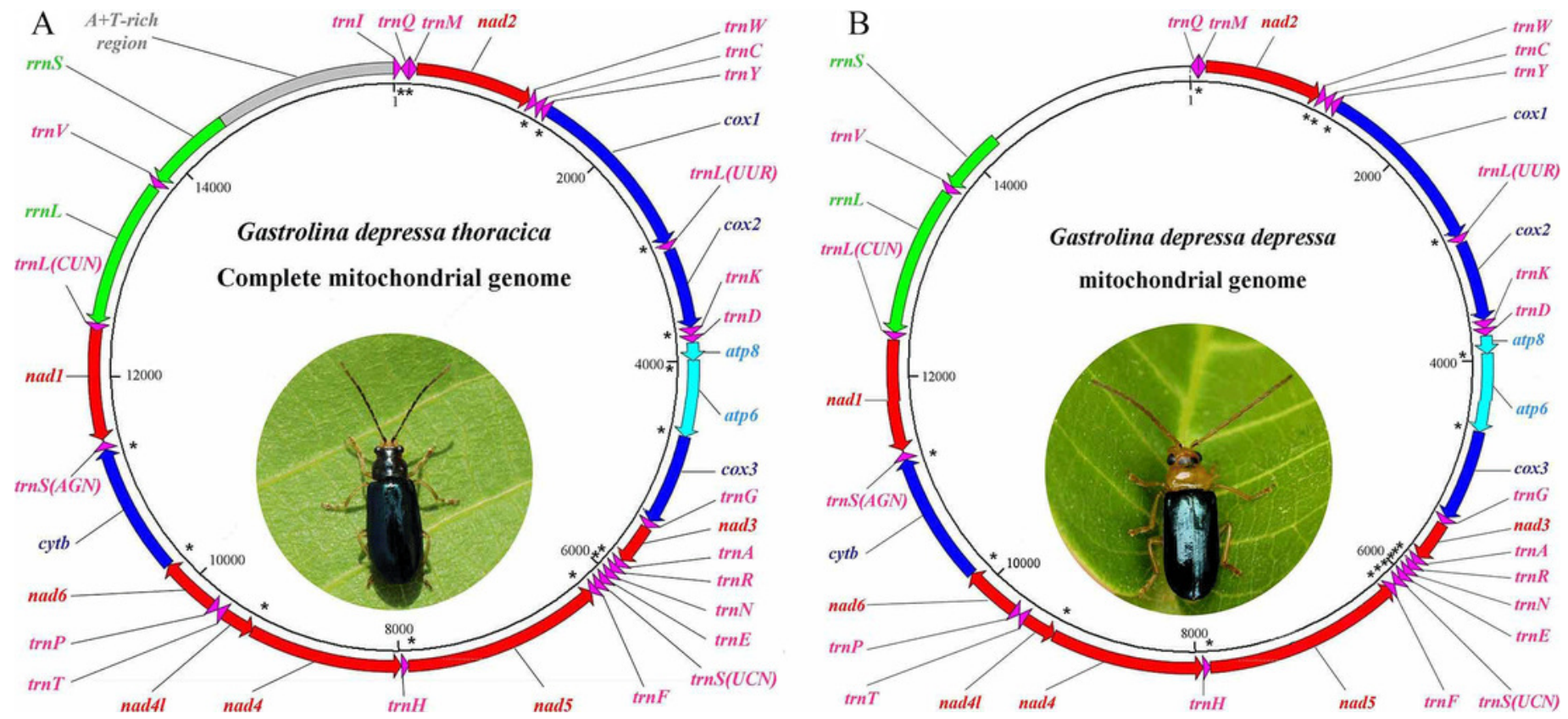
Figure 2

Sequence alignments of atp8/atp6 and nad4/nad4/ of coleopteran insects.

The boxed nucleotides indicate the 7 bp conserved overlaps (ATGATAA).

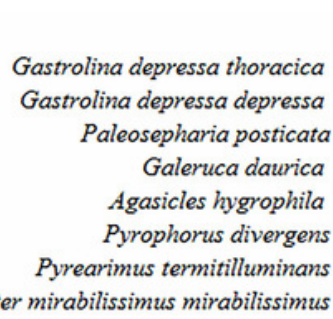

\begin{tabular}{r|l|l}
\multicolumn{1}{r|}{$5^{\prime}-a t p 8$} & 7 bp overlap & $a t p 6-3^{\prime}$ \\
AAATATAACTGAAA & ATGATAA & TAAATTTATTCTCC \\
AATTATAATTGATT & ATGATAA & TAAATTTATTTCT \\
AAATATAACTGAAA & ATGATAA & TAAATTTATTTCA \\
AACTATAACTGAAA & ATGATAA & TAAATTTATTTCT \\
TCAATTAATTGAAA & ATGATAA & TAAATCTATTCTCA \\
AAATTTAACTGAAA & ATGATAA & CAAATCTATTCTCA \\
TCCATCAATTGAAA & ATGATAA & CAAATCTTTTTCT \\
ATTCTTAATTGAAA & ATGATAA & CAAATCTTTTTCA
\end{tabular}

\begin{tabular}{r|l|l|l}
$3^{\prime}-$ nad $4 l$ & 7 bp overlap & nad $4-5^{\prime}$ \\
AATTTTTCTTATTT & ATGATAA & GTTTTATTTTTCT \\
AGTTTTTCAAATTT & ATGATAA & GATTTTTATTTAGT \\
ACATTTTCTTCTTT & ATGATAA & AATTTTTATTTGCA \\
ACTTTTTCTTTTTT & ATGATAA & TATATTTATTAAGA \\
TCTTTTTCTTCTTT & ATGATAA & AATTTATTTCAGA \\
TCTTTTTCTTCTCT & ATGATAA & AGTTTTTGTTTTT \\
ACTTTTAATATTTT & ATGATAA & AGTTTCTTTTTTTT \\
TCAATAAATATATT & ATGATAA & AATTTTTATTGATG
\end{tabular}




\section{Figure 3}

Sequence alignment of the space region between nad1 and trnS2(UCN) of coleopteran species.

The boxed nucleotides indicate the 'TAGTA' conserved motif.

\begin{tabular}{|c|c|c|c|}
\hline & 3'-nadl & & $\underline{\operatorname{trnSer}(U C N)}-5^{\prime}$ \\
\hline Gastrolina depressa thoracica & TTTAGTTAACTAAATT & TAGTA & TAAGTCAATAGAAAAT \\
\hline Gastrolina depressa depressa & TTAGTTAATTATTTTT & & AAT \\
\hline Paleosepharia posticata & $\overline{\text { TTTAGTTAATTATTTT }}$ & TA & $\overline{\mathrm{AAT}}$ \\
\hline daurica & TTTAGT & & $\overline{\mathrm{AAT}}$ \\
\hline ohila & TTTAGT & $\mathrm{T}$ & $\triangle \mathrm{AAAAT}$ \\
\hline Pyrophorus divergens & TTTAGTTAATTAATTT & TA & GATAG \\
\hline Pyrearimus termitilluminans & TATAGTTAATTAAATT & TA & TAAGTTAATAGGTATC \\
\hline ter mirabilissimus mirabilissimus & TATAGTGAATTATTTT & TAGTA & AAAGTTAATAGAGGA \\
\hline
\end{tabular}




\section{Figure 4}

Percentages of amino acid usage in mitochondrial proteins of five species.

Each amino acid is represented by the three-letter abbreviation. Note that leucine and serine are each coded by two different genetic codons, and listed separately.

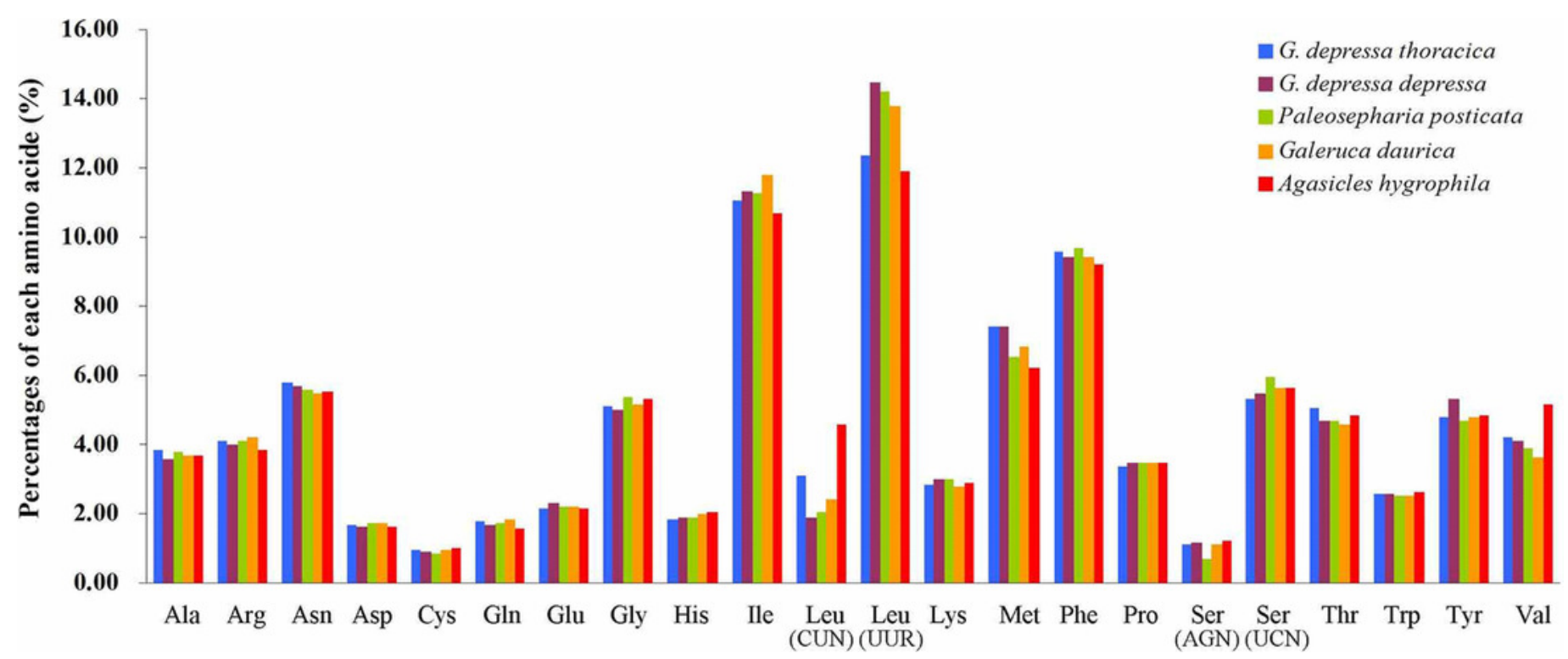




\section{Figure 5}

The mitogenome relative synonymous codon usage (RSCU) across five coleopteran insects.

(A) Gastrolina depressa thoracica. (B) G. depressa depressa. (C) Paleoseparia posticata. (D) Galeruca daurica. (E) Agasicles hygrophila. Codon families are provided on the $\mathrm{x}$-axis. 

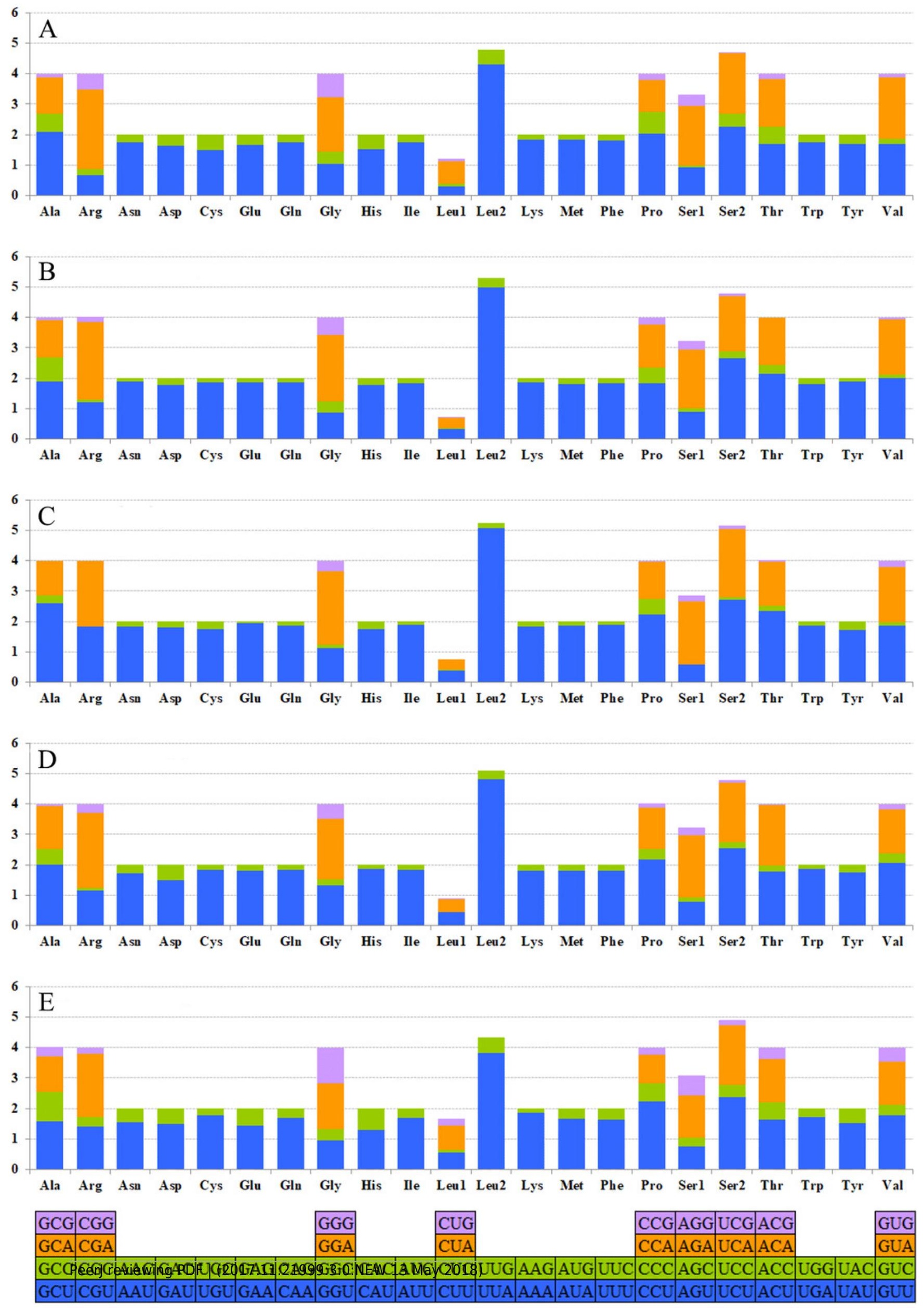


\section{Figure 6}

Codon distribution in five coleopteran insects. CDspT, codons per thousand codons.

(A) Gastrolina depressa thoracica. (B) G. depressa depressa. (C) Paleoseparia posticata. (D)

Galeruca daurica. (E) Agasicles hygrophila. Codon families are provided on the x-axis. Within each family, the percentage of codons located on the $\mathrm{H}$ strand or $\mathrm{L}$ strand is colored with blue or orange, respectively. 

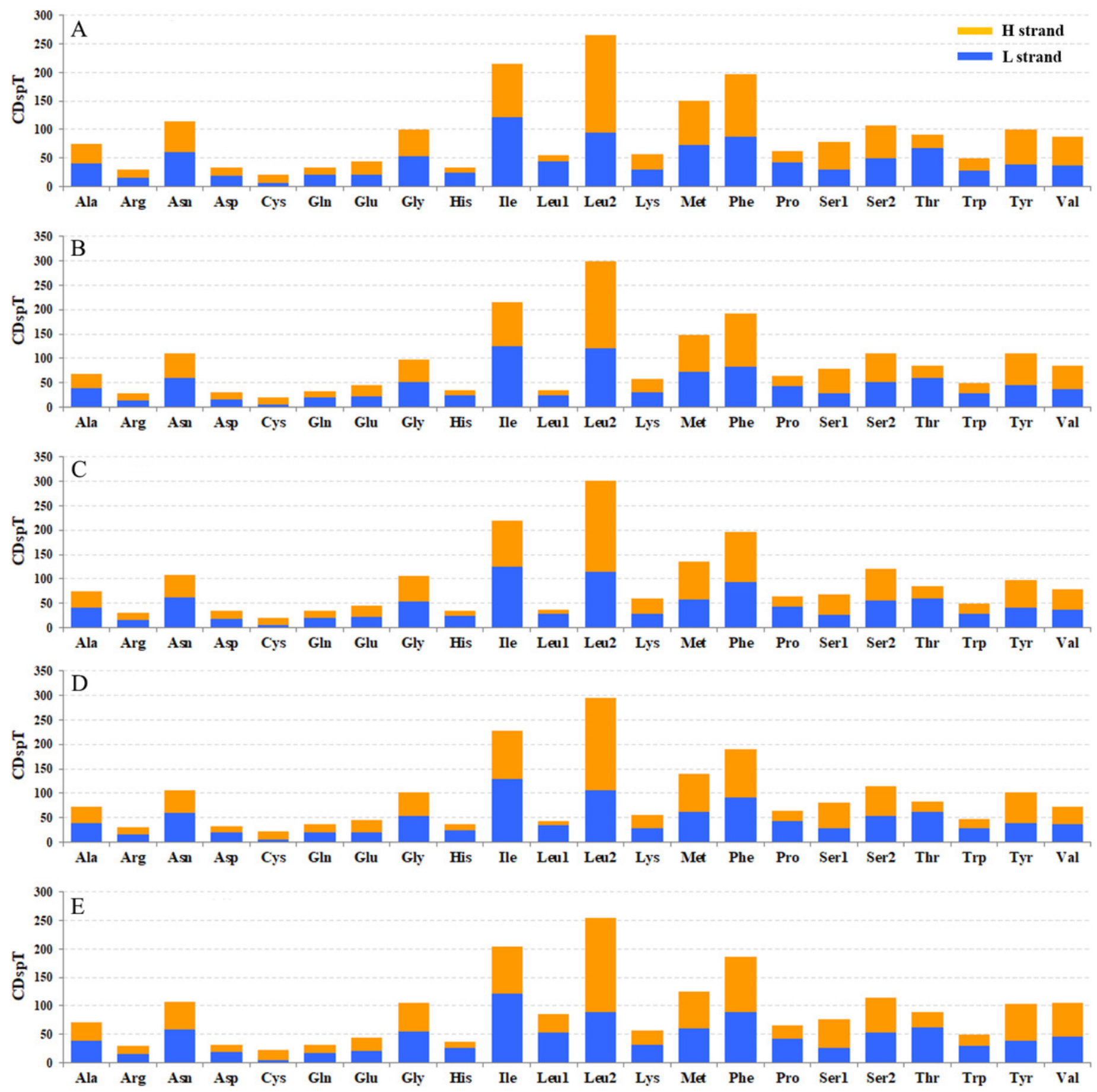
Figure 7

Phylogenetic trees based on (A) the nucleotide and (B) the amino acid datasets for 13 protein-coding genes from the mitochondrial genomes of 36 species.

All the probability values and bootstrap values of the branches were indicated, except for those where the topology of ML and BI was different from different datasets. 


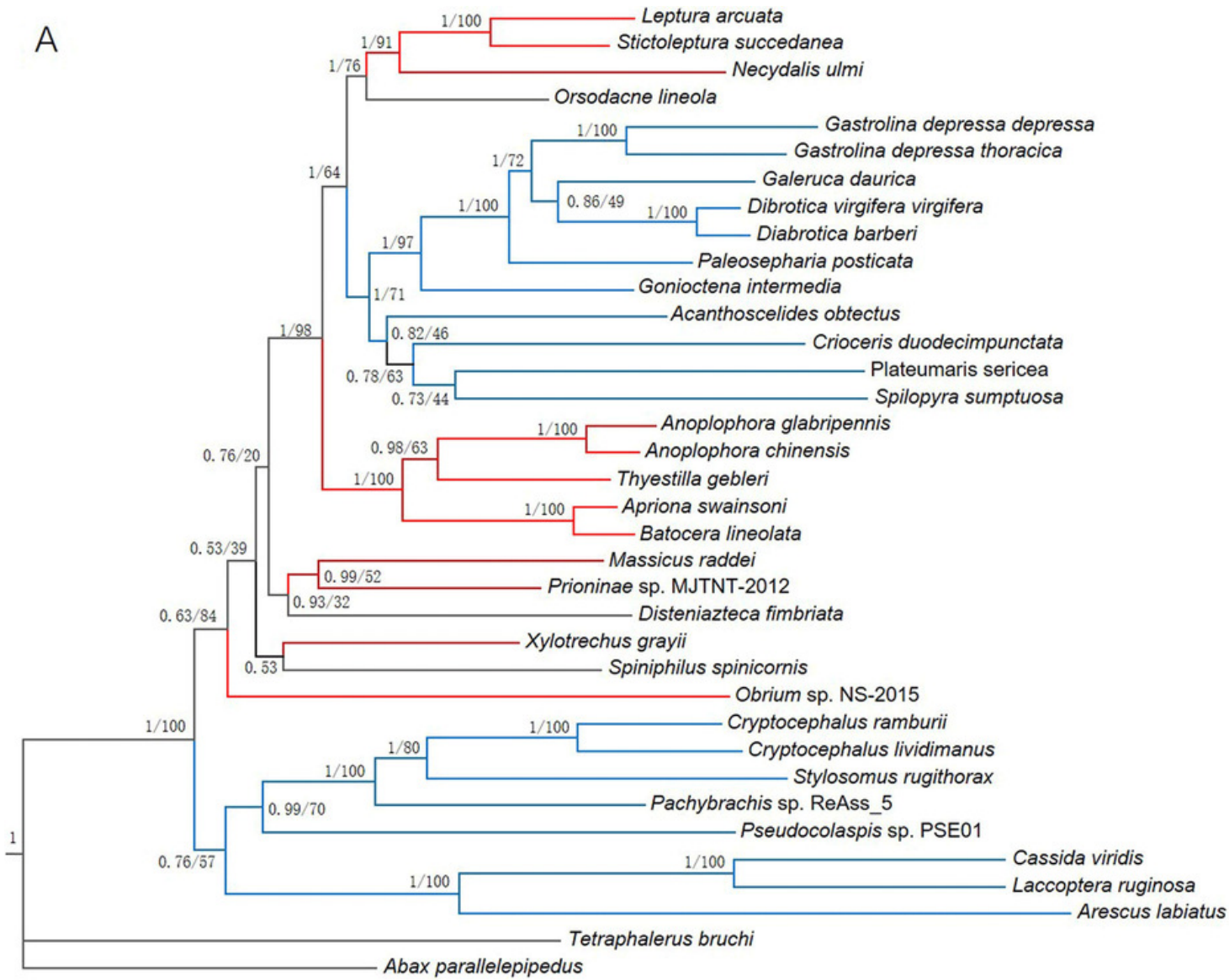

Lepturina

Necydalinae

Orsodacninae

Chrysomelinae

Galerucinae

Chrysomelinae

Bruchinae

Criocerinae

Donaciinae

Spilopyrinae

Lamiinae

Cerambycinae

Prioninae

Disteniinae

Cerambycinae

Vesperinae

Cerambycinae

Cryptocephalinae

Eumolpinae

Cassidinae

Outgroups

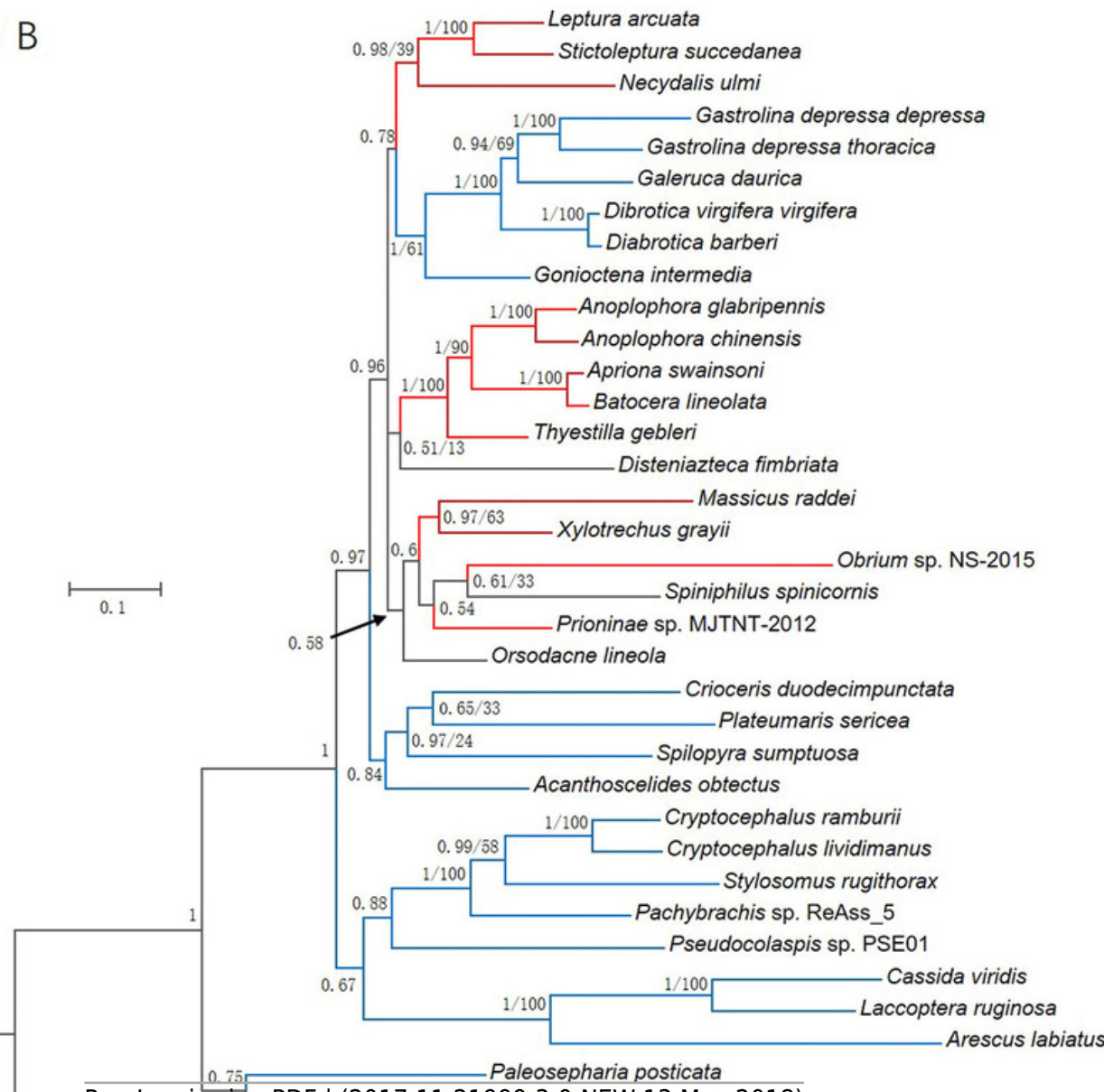

Lepturinae
Necydalinae
Chrysomelinae
Galerucinae
Chrysomelinae
Lamiinae
Disteniinae
Cerambycinae
Cutgroups
Cassidinae
Prioninae
Orsodacninae
Criocerinae
Donaciinae
Bruchinae




\section{Table $\mathbf{1}$ (on next page)}

Primers used in this study to sequence the mitochondrial genomes of Gastrolina depressa thoracica and $G$. depressa depressa. 


\begin{tabular}{|c|c|c|c|c|}
\hline Primer & Forward $\left(5^{\prime} \rightarrow 3^{\prime}\right)$ & Reverse $\left(5^{\prime} \rightarrow 3^{\prime}\right)$ & $\begin{array}{l}\mathrm{Tm} \\
\left({ }^{\circ} \mathrm{C}\right)\end{array}$ & $\begin{array}{c}\text { Length } \\
(\mathrm{kb})\end{array}$ \\
\hline \multicolumn{5}{|c|}{ G. depressa thoracica } \\
\hline 01 & GCCTGAAATGAAAGGATAATTTTGATA & GCTCGGGTATCTACATCTATTC & 55 & 2.2 \\
\hline 02 & GTTAATATAAACTCTTAАССТTCAA & CCGCAAATCTCAGAGCATTG & 49 & 2.3 \\
\hline 03 & ACAATTGGACATCAATGATACTG & ATGACCAGCAATTATATTAG & 51 & 1.1 \\
\hline 04 & TTAGCACATTTAGTTCCACAAGG & TATAATTAGAGCATAATTTTGAAG & 50 & 1.9 \\
\hline 05 & TTTAATTGAAACCAAATTAGAGG & TTTTTGTCGTAATGGTC & 50 & 4.1 \\
\hline 06 & CGCTCAGGCTGATAGCCCCA & AATCGTACTCCGTTTGATTTTGC & 53 & 2.9 \\
\hline 07 & CGAGGTAATGTACCCCGAACCCA & GTGCCAGCAGTTGCGGTTATAC & 58 & 2.8 \\
\hline 08 & ACCTTTATAATTGAGGTATGAAC & ATAATAGGGTATCTAATCCTAG & 51 & 2.0 \\
\hline \multicolumn{5}{|c|}{ G. depressa depressa } \\
\hline 01 & GCCTGATAAAAAGGATTATCTTGATA & TAAACTTCTGGGTGTCCAAAAAATCA & 52 & 2.0 \\
\hline 02 & AATTGGGGGATTTGGAAATTG & CCACAAATTTCTGAACATTG & 49 & 2.0 \\
\hline 03 & ACAATTGGACATCAATGATATTG & AGGGGCTTCTTTTTTCATAA & 47 & 2.3 \\
\hline 04 & GCAGCTGCTTGATATTGACA & TTAGGATGGGATGGTTTGGG & 54 & 2.2 \\
\hline 05 & TTTAATTGAAACCAAATAGAGG & GTTTGTGAGGGGGTTTTAGG & 55 & 3.4 \\
\hline 06 & CCAGAAGAACAAATACCATG & TATCAATAGCAAATCCСССССA & 53 & 2.3 \\
\hline 07 & TTCAGCAATATGAAATTTTGGATC & TTACCTTAGGGATAACAGCGTAA & 53 & 2.4 \\
\hline 08 & CCGGTTTAAACTCAGATCATGTA & GTGCCAGCAGTTGCGGTTATAC & 57 & 1.8 \\
\hline
\end{tabular}




\section{Table 2 (on next page)}

Annotations for the mtgenomes of $G$. depressa thoracica and $G$. depressa depressa.

IGS denotes the length of the intergenic spacer region, for which negative numbers indicate nucleotide overlapping between adjacent genes. $\mathrm{H}$ and $\mathrm{L}$ denote heavy and light strands, respectively. N.C. indicates non-coding sequence. Gdt and Gdd represent G. depressa thoracica and G. depressa depressa, respectively. 


\begin{tabular}{|c|c|c|c|c|c|c|c|c|}
\hline \multirow{2}{*}{ Gene } & \multicolumn{2}{|c|}{ Position } & \multicolumn{2}{|c|}{ IGS/bp } & \multicolumn{2}{|c|}{ Initiation/Stop Codon } & \multirow{2}{*}{-Anticodon } & \multirow{2}{*}{$\begin{array}{l}\text { Coding } \\
\text { Strand }\end{array}$} \\
\hline & Gdt & Gdd & Gdt & Gdd & Gdt & Gdd & & \\
\hline trnI & $1-65$ & - & - & - & & & GAT & $\mathrm{H}$ \\
\hline $\operatorname{trn} Q$ & $65-133$ & $6-74$ & -1 & - & & & TTG & $\mathrm{L}$ \\
\hline $\operatorname{trn} M$ & $133-202$ & $74-140$ & -1 & -1 & & & CAT & $\mathrm{H}$ \\
\hline nad2 & 203-1209 & $141-1154$ & 0 & 0 & ATT/TA & ATT/TAA & & $\mathrm{H}$ \\
\hline $\operatorname{trnW}$ & $1210-1273$ & $1153-1216$ & 0 & -2 & & & TCA & $\mathrm{H}$ \\
\hline $\operatorname{trn} C$ & $1266-1327$ & $1209-1272$ & -8 & -8 & & & GCA & $\mathrm{L}$ \\
\hline $\operatorname{trn} Y$ & $1328-1391$ & $1273-1339$ & 0 & 0 & & & GTA & $\mathrm{L}$ \\
\hline $\operatorname{cox} 1$ & $1384-2931$ & $1332-2879$ & -8 & -8 & ATT/TAA & ATT/TAA & & $\mathrm{H}$ \\
\hline $\operatorname{trnL}(U U R)$ & 2927-2991 & $2875-2939$ & -5 & -5 & & & TAA & $\mathrm{H}$ \\
\hline $\cos 2$ & 2992-3679 & $2940-3627$ & 0 & 0 & $\mathrm{ATT} / \mathrm{T}$ & $\mathrm{ATT} / \mathrm{T}$ & & $\mathrm{H}$ \\
\hline $\operatorname{trnK}$ & $3680-3750$ & $3628-3697$ & 0 & 0 & & & TTT & $\mathrm{H}$ \\
\hline $\operatorname{trn} D$ & $3750-3812$ & $3698-3761$ & -1 & 0 & & & GTC & $\mathrm{H}$ \\
\hline atp 8 & $3813-3968$ & $3762-3917$ & 0 & 0 & ATC/TAA & ATT/TAA & & $\mathrm{H}$ \\
\hline atp6 & $3962-4636$ & $3911-4585$ & -7 & -7 & ATG/TAA & ATG/TAA & & $\mathrm{H}$ \\
\hline $\cos 3$ & $4636-5419$ & $4585-5371$ & -1 & -1 & ATG/T & ATG/T & & $\mathrm{H}$ \\
\hline $\operatorname{trn} G$ & $5420-5483$ & $5372-5435$ & 0 & 0 & & & TCC & $\mathrm{H}$ \\
\hline nad3 & 5484-5835 & $5436-5787$ & 0 & 0 & ATA/T & $\mathrm{ATC} / \mathrm{T}$ & & $\mathrm{H}$ \\
\hline $\operatorname{trn} A$ & 5836-5902 & $5788-5852$ & 0 & 0 & & & TGC & $\mathrm{H}$ \\
\hline $\operatorname{trn} R$ & $5902-5964$ & $5852-5913$ & -1 & -1 & & & TCG & $\mathrm{H}$ \\
\hline $\operatorname{trn} N$ & $5964-6027$ & $5911-5974$ & -1 & -3 & & & GTT & $\mathrm{H}$ \\
\hline $\operatorname{trnS}(U C N)$ & $6028-6094$ & $5971-6034$ & 0 & -4 & & & TCT & $\mathrm{H}$ \\
\hline $\operatorname{trn} E$ & $6095-6157$ & 6033-6095 & 0 & -2 & & & TTC & $\mathrm{H}$ \\
\hline $\operatorname{trn} F$ & $6158-6220$ & 6094-6159 & 0 & -2 & & & GAA & $\mathrm{L}$ \\
\hline nad5 & $6204-7925$ & $6140-7867$ & -17 & -20 & ATT/TAA & ATT/TAA & & $\mathrm{L}$ \\
\hline $\operatorname{trnH}$ & 7923-7984 & $7865-7928$ & -2 & -3 & & & GTG & $\mathrm{L}$ \\
\hline nad4 & $7985-9317$ & $7929-9261$ & 0 & 0 & ATG/T & ATG/T & & $\mathrm{L}$ \\
\hline nad4l & 9311-9595 & $9255-9539$ & -7 & -7 & ATG/TAA & ATG/TAA & & L \\
\hline $\operatorname{trnT}$ & $9599-9660$ & $9543-9606$ & 3 & 3 & & & TGT & $\mathrm{H}$ \\
\hline $\operatorname{trn} P$ & $9661-9723$ & $9607-9670$ & 0 & 0 & & & TGG & $\mathrm{L}$ \\
\hline nad6 & $9726-10226$ & 9673-10143 & 2 & 2 & ATA/TAA & ATT/TAA & & $\mathrm{H}$ \\
\hline$c o b$ & $10226-11365$ & $10143-11282$ & -1 & -1 & ATG/TAG & ATG/TAG & & $\mathrm{H}$ \\
\hline $\operatorname{trn} S(A G N)$ & $11364-11430$ & $11281-11345$ & -2 & -2 & & & TGA & $\mathrm{H}$ \\
\hline nad1 & $11448-12398$ & $11363-12313$ & 17 & 17 & TTG/TAG & TTG/TAG & & $\mathrm{L}$ \\
\hline $\operatorname{trnL}(\mathrm{CUN})$ & $12400-12464$ & $12315-12379$ & 1 & 1 & & & TAG & $\mathrm{L}$ \\
\hline$r r n L$ & $12465-13738$ & $12380-13661$ & 0 & 0 & & & & $\mathrm{~L}$ \\
\hline $\operatorname{trn} V$ & $13739-13806$ & $13662-13730$ & 0 & 0 & & & TAC & $\mathrm{L}$ \\
\hline$r r n S$ & $13807-14551$ & $13731-14281$ & 0 & 0 & & & & $\mathrm{~L}$ \\
\hline A+T-rich region & 14552-16109 & - & 0 & - & & & & N.C. \\
\hline
\end{tabular}




\section{Table 3 (on next page)}

Nucleotide compositions in the mitogenomes of $G$. depressa depressa, $G$. thoracica depressa, Paleosepharia postivata, Galeruca daurica and Agasicles hygrophila. 


\begin{tabular}{|c|c|c|c|c|c|c|c|c|c|c|c|c|c|c|c|}
\hline & \multicolumn{3}{|c|}{ G. depressa depressa } & \multicolumn{3}{|c|}{ G. depressa thoracica } & \multicolumn{3}{|c|}{ Paleosepharia postivata } & \multicolumn{3}{|c|}{ Galeruca daurica } & \multicolumn{3}{|c|}{ Agasicles hygrophila } \\
\hline & $\mathrm{A}+\mathrm{T}$ & $\begin{array}{c}\text { AT } \\
\text { skew }\end{array}$ & $\begin{array}{c}\text { GC } \\
\text { skew }\end{array}$ & $\mathrm{A}+\mathrm{T}$ & $\begin{array}{c}\text { AT } \\
\text { skew }\end{array}$ & $\begin{array}{c}\text { GC } \\
\text { skew }\end{array}$ & $A+T$ & $\begin{array}{c}\text { AT } \\
\text { skew }\end{array}$ & $\begin{array}{c}\text { GC } \\
\text { skew }\end{array}$ & $\mathrm{A}+\mathrm{T}$ & $\begin{array}{c}\mathrm{AT} \\
\text { skew }\end{array}$ & $\begin{array}{c}\text { GC } \\
\text { skew }\end{array}$ & $\mathrm{A}+\mathrm{T}$ & $\begin{array}{c}\text { AT } \\
\text { skew }\end{array}$ & $\begin{array}{c}\text { GC } \\
\text { skew }\end{array}$ \\
\hline Protein-coding genes & 77.9 & -0.143 & 0.018 & 75.2 & -0.133 & -0.005 & 78.0 & -0.150 & 0.006 & 77.0 & -0.141 & -0.006 & 72.4 & -0.152 & -0.018 \\
\hline First codon position & 73.3 & -0.040 & 0.225 & 71.3 & -0.010 & 0.194 & 72.3 & -0.050 & 0.227 & 72.4 & -0.025 & 0.188 & 68.9 & -0.021 & 0.153 \\
\hline Second codon position & 69.7 & -0.384 & -0.117 & 69.2 & -0.387 & -0.125 & 68.6 & -0.391 & -0.141 & 68.7 & -0.394 & -0.112 & 68.4 & -0.395 & -0.117 \\
\hline Third codon position & 90.6 & -0.040 & -0.135 & 85.2 & -0.03 & -0.153 & 93.2 & -0.049 & -0.211 & 90.1 & -0.042 & -0.210 & 80.0 & -0.058 & -0.128 \\
\hline Protein-coding genes- $\mathrm{H}$ strand & 76.4 & -0.087 & -0.106 & 73.3 & -0.050 & -0.162 & 76.6 & -0.112 & -0.110 & 75.1 & -0.089 & -0.134 & 70.7 & -0.084 & -0.145 \\
\hline First codon position & 70.8 & 0.057 & 0.132 & 68.4 & 0.112 & 0.079 & 69.7 & 0.032 & 0.140 & 69.5 & 0.064 & 0.098 & 66.7 & 0.079 & 0.071 \\
\hline Second codon position & 68.0 & -0.361 & -0.221 & 66.8 & -0.364 & -0.209 & 67.2 & -0.361 & -0.217 & 67.2 & -0.368 & -0.202 & 67.3 & -0.70 & -0.203 \\
\hline Third codon position & 90.2 & 0.005 & -0.470 & 84.8 & 0.066 & -0.562 & 92.8 & -0.041 & -0.681 & 88.5 & 0.001 & -0.557 & 78.1 & 0.025 & -0.388 \\
\hline Protein-coding genes-L strand & 80.1 & -0.227 & 0.246 & 78.8 & -0.246 & 0.286 & 80.4 & -0.206 & 0.229 & 80.2 & -0.219 & 0.255 & 75.3 & -0.256 & 0.224 \\
\hline First codon position & 77.0 & -0.167 & 0.410 & 76.1 & -0.149 & 0.417 & 76.5 & -0.170 & 0.405 & 77.0 & -0.153 & 0.380 & 72.5 & -0.168 & 0.311 \\
\hline Second codon position & 72.1 & -0.431 & 0.053 & 71.6 & -0.433 & 0.044 & 70.8 & -0.437 & -0.005 & 71.1 & -0.443 & 0.051 & 70.1 & -0.434 & 0.035 \\
\hline Third codon position & 91.2 & -0.116 & 0.429 & 88.7 & -0.177 & 0.617 & 93.8 & -0.062 & 0.659 & 92.6 & -0.110 & 0.657 & 83.1 & -0.183 & 0.414 \\
\hline
\end{tabular}

1 